FORUM Volume 58, Number 3, 2016 www.wwwords.co.uk/FORUM

http://dx.doi.org/10.15730/forum.2016.58.3.399

\title{
Choosing Silence for Equality in and through Schooling
}

HELEN E. LEES

\section{ABSTRACT}

This article considers silences and equality as combined from a theoretical perspective. Equality in and through chosen, deliberate and regular silence experience is seen as an equaliser: if no one is speaking no one can dominate. The article uses a bifurcated concept of silence: weak, negative forms and strong, positive forms. Only the strong forms are seen here as conducive to equality. Their opposite - a silencing - is seen as the creator of inequality. The argument suggests in order to tackle inequality in neo-liberal education a radical, cost-free, non-partisan solution of silence experience is available.

The only way to fight a hegemonic discourse is to teach ourselves and others alternative ways of seeing the world. (Brodkey, 1996, p. 113)

\section{Introduction: conceptualising silence for schools}

Speaking about silence is not an easy task. For a start, it is the ineffable. It is also, as without discourse, a hard concept to pin down through spoken language or thought. Schwartz (1996) called it 'slippery' for good reason. This range or lack of boundaries may explain the astonishingly large literature, across multiple disciplines involving the social sciences, the humanities and the natural sciences (e.g. Cage, 1961; Bruneau, 1973; Clair, 1998; Fonteneau, 1999; Aarts, \& Dijksterhuis, 2003; Gardezi, et al, 2009; Cooper, 2012; Schmidt, 2016). Part of the 'popularity' of the idea of silence or indeed, its fact as a large part of our life, is that we can see it and experience it in many ways, including: as lack of noise, as chosen experience, as atmosphere, as denial of self-expression, as environmental condition, as artistic product, as religious communication.

In previous work I spent considerable effort getting to grips with this slipperiness. I wanted to talk about the use of and value for schools of silence. This work (Lees, 2012) ended up describing uses in schools of techniques to access silence such as meditation and mindfulness, as well as untechniqued approaches involving, for instance, a teacher walking gently out of the classroom (Ollin, 2008) or putting a quiet space in the corner of the room for children to sit in (Haskins, 2010). But the core of the contribution was perhaps not on profiling the variety of what goes on in schools - as interesting as that Helen E. Lees 400 turned out to be - but theoretical work to characterise silence, putting 'markers in the sand' (Lees, 2012, p. ix) so that fruitful, non-slippery discussion could ensue: silence was deemed 'weak' or 'strong', as explained below. 
The reason this theoretical work matters is because so much previous work on silence in schooling has been on the negative kind: silence used as a form of oppression, silencing and denial of voice or denial of self-expression in education. Such silence is historically an embedded part of the conduct of school learning and behaviours: telling/compelling children to be quiet (rather than asking them to take account of others) or imposing silent line-ups outside classrooms or silent assemblies or silent, isolating work as punishment or the ignoring of homosexual or sexist bullying as a silence (Walkerdine, 1985; Leander, 2002). We can identify weak silence as playing an active role in schools. The concept is well known.

There is, however, too much silence about positive, strong silence: a silence strong enough to bring forth benefits into the lives of children and school staff. Creating a binary of weak and strong out of the non-binary material of silence (it lacks capacity or interest itself to make contrasts such as 'good/bad', 'weak/strong', 'positive/negative') was an act of theory done to enable us to focus more on the material of silence as an educational benefit, tool, 'strange' curricula item, practice for education, rather than as an incidental or accidental malignant part of the hidden curriculum. Assumptions in the past of talk about silence in schooling have largely excluded the possibility that it might be a good thing.

In bifurcating silence for schools we are able to acknowledge the history of 'silence' in schooling but focus going forward on what silence really is: a material with content and effects which, under certain conditions (e.g. teachers who themselves practise with silence in their own lives as a matter of interest and importance), and with specific approaches (cumulative, regular engagement - rather than ad hoc attention - for example), could be used for educational and social or personal gains. This article focuses on the potential gains of equality for schooling that silence as positive practice could present if well used. As Zembylas and Michaelides state, 'At what cost to the individual, to teaching and learning, and to society in general does education ignore the pedagogical value of silence?' (2004, p. 193).

\section{A Positive Vision of Silence for Schooling}

In recent times a developing number of works have aimed to characterise and profile strong silence for schooling. Each in turn has achieved a uniqueness due to the wide landscape that silence offers as 'angle' or 'approach'. These works exploring silence as a positive function range from looking at silence in relation to teacher-student participation and 'ways to make silence an affirmative part of the classroom dynamic' (Schultz, 2009, p. 144), considerations of quiet students (Reda, 2009), work on the use of school spaces for silence (Alerby, 2012) and binary issues of education as linked to silence (Kalamaras, 1994). My own book (Lees, 2012) offers a specific focus on silence as a democratising power for schools. There I argue silence is an equaliser, because of a lack of any form of discourse. To achieve strong silence people need to not talk: everyone in the silence is equal with no chance to delineate position or status.

As educationists, the above-mentioned authors all think silence is useful, educationally speaking. Edited volume chapters and journal articles also come to the same conclusion, each in their way (e.g. among many, Caranfa, 2004; Zembylas \& Michaelides, 2004; Ollin, 2008; Waks, 2008; Cooper, 2012). 
Reports of negative outcomes from strong silence practices are hard to find: 'no studies report any adverse affects' (Burke, 2010, p. 136). How is this possible? What might be necessary to ensure strong silence is not or does not become its evil twin, weak silence?

\section{Where and What Should Silence in Schools Be?}

Positive silence practices might well be best placed outside the formal curriculum and its role in institutional improvement. Silence is more in tune with postmodern attitudes to curriculum represented through, for instance, complexity theory where emergence is a key concept (see Doll, 1993, Osberg et al, 2008). For this, however, it is possible that alternative educational approaches (see Lees \& Noddings, 2016) will be needed to accommodate the difference both of silence and its most appropriate avenues for emergence. In other words, the conservatism of schooling and teachers (Children Schools and Families Committee, 2010) could get in the way, whereas alternative approaches may open up minds to accept the radical innovation and potential of silence for schooling.

The situation with silence in schools is at present often troubled by a lack of alternative vision of education. Current neo-liberal adoption of silence practices - and especially mindfulness as the most fashionable of all - are to be suspected for an almost entire lack of questioning of the institutional environments into which these practices are being introduced. Most contemporary schooling structurally operates against equality in its interrelational dynamics and social outputs (Reay, 2006, 2012); even 'otherwise' practices such as parents deliberately choosing 'common' schooling are uncovered as unfortunately implicit in perpetuating a lack of interest in genuine equality seeking and making (see Reay et al, 2008). Silence practices are being enacted as a part of this neo-liberal picture where equality for all does not matter. However, they ought not to be thus involved. The character of chosen silence as a radical material suited to equality and equalising and requiring mutuality of consent seeking and receiving (see Lees, 2016) goes against this, indicating that such initiatives, without a democratic vision, will fail to attract student volition (Lees, 2012).

Silence offers difference and dissent from neo-liberal education. As a radical material it has huge potential for the formation of equality. As Glenn (2004) states, it is possible, on account of silence's disruption as 'empowered action' (p. 156) of the rhetoric of support for neo-liberal agendas to: 'use silence to embody new ways to challenge and resist domination and hierarchy at the Helen E. Lees 402 same time as it disrupts and transforms it' (p. 157). Not speaking - and doing this together - is to disrupt the assumption of support for domination and hierarchy pervasive in the everyday picture of schooling.

What silence offers a current social scene in the United Kingdom of ignorance and disinterest in the value of equality seeking and making (Wilkinson, \& Pickett, 2009; Dorling, 2015) is a common space - in silence - for re-engagement with commonality and community (Fielding \& Moss, 2011). Through its practices of techniques and non-techniques a gentle path to a cleared, clearing and clearer head where being aware of self and other is quite simply easier occurs: cognitively, emotionally and spiritually (Berryman, 1999). Whilst this seems soft, silence is both soft and then also, in other and connected modes, a campaigning force against injustice: 'at times it is the silent person who uses his or her silence to gain control of the situation - to attain power' 
(Kurzon, 1992, p. 93); 'Silence is not necessarily a passive act of submission or repression. It can be a challenge to the monologue of dominant discourses that ruptures the power play between speakers and listeners, and creates conducive conditions for the "invisible," the "unsaid" to emerge' (Dhawan, 2012, p. 58).

How and why silence practices might enter any school's curriculum will be interesting to watch since silence as a practice struggles to 'fit' current conceptions of curricula as knowledge banking (Doll, 1993). For example: 'there is currently no curriculum for mindfulness or any clearly articulated objectives for mindfulness in schools' (Burnett, 2009, p. 25). Whilst things are changing fast how does one write a curriculum for silence? Only practices can be programmed in. Nevertheless, when this does happen the full complexity of silence emerges - as if appearing on a stage in front of an audience. It can be experienced and even seen in its affects as a material demanding democratic interaction to be real, acceptable and effective experience for benefits (Lees, 2012). In this sense silence can talk to schooling and teach schooling, rather than be mere deliverable content.

\section{Equality in Education in and through Silence?}

How and Why Silence is cost-free and available by birth. It is independent of social status or forms of social and cultural capital, and as such, it has the potential to disrupt sedimented status quos and be a 'yet to be thought' (Bernstein, 1996, p. 44) solution to social injustice from and in schooling.

Silence has power (Jaworski, 1993; Kenny, 2011). The literature is clear that it offers ways to manage behaviours for interpersonal tolerance (Erricker \& Erricker, 2001), enable amelioration of mental health concerns (Huppert \& Johnson, 2010), decrease stress (Gold et al, 2009) and improve relationships (Von Wright, 2012). In being a material which slowly, over time and regular engagement, can calm the brain's ruminations, the perspective, consciousness and thought-toaction responses are rendered less likely to be reactive, emotionally charged and destructive. We find that impacts of a 'healing' kind from engagement with silence abound in the literature (e.g. Duran-Serrano \& Vidal 2012). In essence, whatever the issue, in connection with or through exposure to chosen silence, the edges of difficulties such as forms of injustice are rendered more responsive and flexible, if not wholly addressed.

Can silence really offer equality? The key to this is in two areas: its lack of use of discourse, as mentioned, and the need for democratic negotiations on account of the conditions involved requiring choice for it and consent received. First, speaking causes problems. When people speak it is possible to delineate inequality: 'I am better, I am richer, you are stupid, you are ugly, I am going to this good university, you are not worthy to work in a profession and should labour instead'. If we don't say any of these things people are not subjected to forces of inequality through discourse use. Second, if you choose to use silence, all well and good. However, you are dependent on others to not spoil your silence by talking over it. This creates a situation of negotiated shared experience: I am silent and please don't spoil mine, OK? Which means everyone, if all are in agreement, is silent, independent of who wants it or not. With such agreements can come mutual respect filtering through school environments as a 'sweetening' influence (Lees, 2012). 
Furthermore, choice is essential for silence to be experienced positively and to be strong enough to be beneficial for all. Choice among all is a marker of equality, rather than inequality. Thus, users of silence in school communities are taking a part in equalising through choice enactment, a non-binary experience and a positive encounter with experiences of not being delineated. All it takes is for a community to agree to experience silence, however briefly, but necessarily on a regular basis.

\title{
Conditions and Approaches for Silence
}

Silence has a surprisingly intricate and deep nature, yet we find there are conditions and approaches needed for managing it, which, over time, are filtering into modern practice. Scientific literature recognises how cumulative practice helps the efficacy of silence practices in schools (Huppert \& Johnson, 2010). It becomes evident that all matters silent need care:

\begin{abstract}
Adapting $\mathrm{MBSR} / \mathrm{MBCT}$ [mindfulness] programs for younger participants requires attention to age-related developmental needs (attention span, cognitive capacities, language, physicality, relevant content), and issues arising from the fact that children are somewhat embedded within their family (and school) systems, and varyingly reliant on adults ... as well as ethical issues, including ensuring informed consent from both children and caregivers. (Burke, 2010, pp. 142-143)
\end{abstract}

Burke highlights the 'cautious 'small steps' approach needed in the early stages of research into a novel intervention' (2010, p. 139). Long-term practitioners in school environments speak of the need to manage the silence through talk, negotiations, respect for individual interests or lack of it in its use and so on, but especially a need for silence to be done with consent received rather than Helen E. Lees 404 achieved via coercion (Lees, 2012). Not all 'interventionists', however, either choose to adopt such care or even know how. This is a challenge that those of us who are committed to developing silence practices need to overcome.

\section{Conclusion}

Over time these lessons of equality making and experiencing from silence are lessons not just for education in schools but are mental experiences acting as an anchor-memory to return to in other contexts. If you think and find you are equal in silence you can know it to be possible to be 'equal', and in thus experiencing it you can believe equality is possible more generally. Silence, then, has the power to be a political experience of conscientisation (Freire, 1972). Equality without words is a change that can come to education and come through education to society so long as we are all, sometimes and together with commitment, electively quiet.

\section{References}

Aarts, H. \& Dijksterhuis, A. (2003) The Silence of the Library: environment, situational norm, and social behavior, Journal of Personality and Social Psychology, 84(1), 18-28.

http://dx.doi.org/10.1037/0022-3514.84.1.18 
Alerby, E. (2012) Om Tystnad - I Pedagogiska Sammanhang [About Silence - in Educational Settings]. Lund: Studentlitteratur.

Bernstein, B. (1996) Pedagogy, Symbolic Control and Identity: theory, research, critique. London: Taylor \& Francis. Berryman, J.W. (1999) Silence is Stranger Than it Used to Be: teaching silence and the future of humankind, Religious Education, 94(3), 257-272.

http://dx.doi.org/10.1080/0034408990940302

Brodkey L. (1996) Writing Permitted in Designated Areas Only. Minneapolis: University of Minnesota Press.

Bruneau, T. (1973) Communicative Silences: forms and functions, Journal of Communication, 23, 1746. http://dx.doi.org/10.1111/j.1460-2466.1973.tb00929.x

Burke, C.A. (2010) Mindfulness-based Approaches with Children and Adolescents: a preliminary review of current research in an emergent field, Journal of Child and Family Studies, 19(2), 133-144. http://dx.doi.org/10.1007/s10826-009-9282-x

Burnett, R. (2009) Mindfulness in Schools: learning lessons from the adults - secular and Buddhist. Sunderland: Sunderland University.

Cage, J. (1961) Silence: lectures and writings. Middletown, CT: Wesleyan University Press.

Caranfa, A. (2004) Silence as the Foundation of Learning, Educational Theory, 54(2), 211-230. http://dx.doi.org/10.1111/i.1741-5446.2004.00015.x

Children Schools and Families Committee (2010) From Baker to Balls: the foundations of the education system. Ninth Report of Session 2009-2010. London: House of Commons.

Clair, R.P. (1998) Organising Silence: a world of possibilities. Albany, NY: State University of New York Press. CHOOSING SILENCE FOR EQUALITY 405

Cooper, D.E. (2012) Silence, Nature and Education, in A. Kristiansen \& H. Hägg (Eds) Attending to Silence. Kristiansand: Portal Books.

Dhawan, N. (2012) Hegemonic Listening and Subversive Silences: ethical-political imperatives, in A. Lagaay \& M. Lorber (Eds) Destruction in the Performative (Critical Studies Series), pp. 47-60. Amsterdam: Rodopi.

Doll, W.E. (1993) A Post-modern Perspective on Curriculum. New York: Teachers College Press. Dorling, D. (2015) Injustice: why social inequality still persists, 2nd edn. Bristol: Policy Press.

Duran-Serrano, Y. \& Vidal, L. (2012) Silence Heals. Salisbury: Non Duality Press.

Erricker, C. \& Erricker, J. (Eds) (2001) Meditation in Schools: calmer classrooms. London: Continuum. Fielding, M. \& Moss, P. (2011) Radical Education and the Common School: a democratic alternative. London: Routledge.

Fonteneau, F. (1999) L'éthique du Silence: Wittgenstein and Lacan. Paris: Éditions du Seuil. 
Freire, P. (1972) Pedagogy of the Oppressed. Harmondsworth: Penguin.

Gardezi, F., Lingard, L., Espin, S., et al (2009) Silence, Power and Communication in the Operating Room, Journal of Advanced Nursing, 65(7), 1390-1399. http://dx.doi.org/10.1111/j.1365-

$\underline{2648.2009 .04994 . x}$

Glenn C. (2004) Unspoken: a rhetoric of silence. Carbondale: Southern Illinois Press.

Gold, E., Smith, A., Hopper, L., et al (2009) Mindfulness-Based Stress Reduction (MBSR) for Primary School Teachers, Journal of Child and Family Studies, 19(2), 184-189.

http://dx.doi.org/10.1007/s10826-009-9344-0

Haskins, C. (2010) Integrating Silence Practices into the Classroom: the value of quiet, Encounter: Education for Meaning and Social Justice, 23(3), 1-6.

Huppert F.A. \& Johnson D.M. (2010) A Controlled Trial of Mindfulness Training in Schools: the importance of practice for an impact on well-being, Journal of Positive Psychology, 5, 264-274. http://dx.doi.org/10.1080/17439761003794148

Jaworski, A. (1993) The Power of Silence. London: SAGE. Kalamaras, G. (1994) Reclaiming the Tacit Dimension. New York: State University of New York Press.

Kenny, C. (2011) The Power of Silence. London: Karnac Books Kurzon, D. (1992) When Silence May Mean Power, Journal of Pragmatics, 18(1), 92-95. http://dx.doi.org/10.1207/S15326950DP3402 4

Leander, K.M. (2002) Silencing in Classroom Interaction: producing and relating social spaces, Discourse Processes, 34(2), 193-235.

Lees, H.E. (2012) Silence in Schools. Stoke-on-Trent: Trentham Books.

Lees, H.E. (2016) Educational Mutuality, in H.E. Lees \& N. Noddings (Eds) The Palgrave International Handbook of Alternative Education. London: Palgrave Macmillan. http://dx.doi.org/10.1057/978-1$\underline{137-41291-111}$

Lees, H.E. \& Noddings, N. (Eds) (2016) The Palgrave International Handbook of Alternative Education. London: Palgrave.

Ollin, R. (2008) Silent Pedagogy and Rethinking Classroom Practice: structuring teaching through silence rather than talk, Cambridge Journal of Education, 38(2), 265-280.

http://dx.doi.org/10.1080/03057640802063528

Osberg, D., Biesta, G. \& Cilliers, P. (2008) From Representation to Emergence: complexity's challenge to the epistemology of schooling, Educational Philosophy and Theory, 40(1), 213-227.

http://dx.doi.org/10.1111/j.1469-5812.2007.00407.x

Reay, D. (2006) The Zombie Stalking English Schools: social class and educational inequality, British Journal of Educational Studies, 54(3), 288-307. http://dx.doi.org/10.1111/j.1467-8527.2006.00351.x 
Reay, D. (2012) What Would a Socially Just Education System Look Like? Saving the Minnows from the Pike, Journal of Education Policy, 27(5), 587-599.

http://dx.doi.org/10.1080/02680939.2012.710015

Reay, D., Crozier, G., James, D., et al (2008) Re-invigorating Democracy? White Middle Class Identities and Comprehensive Schooling, Sociological Review, 56(2), 238-255.

http://dx.doi.org/10.1111/i.1467-954x.2008.00786.x

Reda, M.M. (2009) Between Speaking and Silence. New York: State University of New York Press.

Schmidt, K. (2016) Eine Sonderbare Stille. Warum der Tod ins Leben gehört. Vienna: Christian Brandsätter Verlag.

Schultz, K. (2009) Rethinking Classroom Participation: listening to silent voices. New York: Teachers College Press. Schwartz, L. (1996) Understanding Silence. PhD thesis, University of Glasgow.

Waks, L.J. (2008) Listening from Silence: inner composure and engagement, Paideusis, 17(2), 65-74. Walkerdine, V. (1985) On the Regulation of Speaking and Silence: subjectivity, class and gender in contemporary schooling, in V. Walkerdine, C. Urwin \& C. Steedman (Eds) Language, Gender and Childhood. London: Routledge \& Kegan Paul.

Wilkinson, R. \& Pickett, K. (2009) The Spirit Level: why more equal societies almost always do better. London: Allen Lane. von Wright, M. (2012) Silence in the Asymmetry of Educational Relations, in A. Kristiansen \& H. Hägg (Eds) Attending to Silence. Kristiansand: Portal Books.

Zembylas, M. \& Michaelides, P. (2004) The Sound of Silence in Pedagogy, Educational Theory, 54(2), 193-210. http://dx.doi.org/10.1111/i.0013-2004.2004.00005.x

HELEN E. LEES is a Senior Lecturer in Education Studies at Newman University, Birmingham, and founding Editor-in-Chief of Other Education: the journal of educational alternatives (www.othereducation.org). Work is here: https://newman.academia.edu/HelenELees Correspondence: h.lees@newman.ac.uk 